\title{
EKSEKUSI JAMINAN FIDUSIA DI BANK SYARIAH MANDIRI KOTA MALANG DI TINJAU DARI FATWA DSN MUI NOMOR 68 TAHUN 2008
}

\author{
Solihan Makruf \\ Jurusan Hukum Bisnis Syariah \\ Fakultas Syariah, UIN Maulana Malik Ibrahim Malang \\ Email: Solihaniny@yahoo.com
}

In the modern era bankings are not only collecting funds from the society and distributing them as loans. It is important for us to observe whether the activities are halal or not from Islamic perspective. Therefore, it is important to build dependable islamic bankings with high Islamic law awareness. The study has three research questions. They are: 1) How is the practice of fiduciary guarantee in Bank SyariahMandiri Kota Malang? 2) What is the perspective of National Sharia Board of MUI on fiduciary guarantee in Bank Syariah Mandiri Kota Malang? 3) How is the execution of fiduciary guarantee as the consequence of debtor's failure in paying their debt in Bank Syariah Mandiri Malang?The study employs sociological or empirical law method. It is an approach to analyze an effectively established legislation or law.It analyzes qualitatively the implementation of fiduciary guarantee in Bank Syariah Mandiri Kota Malang. The dataconsists of primary data from interviews and secondary data from the library study. The writer uses descriptive analytical data analysis.

Hasil penelitian mwnunjukan bahwa pelaksanaan jaminan dan eksekusi jaminan fidusia terhadap barang jaminan tidak sesuai dengan hukum yang ada-dari perspektif hukum positif tentang jaminan fidusia dan dari perspektif hukum islam yang didasarkan pada fatwa Badan Syariah Nasional. Kesimpulannya, Bank Islam sering melakukan kesalahan pada prosedur eksekusi jaminan fidusia.

Dari analisis tersebut, dapat disimpulkan bahwa prosedur jaminan fidusia dan eksekusinya di Bank Syariah Mandiri Kota Malang tidak sesuai dengan hukum yang ada. Seharusnya bank ini menerapkan prosedur sesuai dengan prinsip syariah dan fatwa Badan Syariah Nasional MUI, sebuah institusi yang menaungi bank-bank syariah dan hukum tentang jainan fidusia untuk memastikan pratik tersebut tidak akan merugikan pihak-pihak lain.

Kata kunci :Bank Islam, jaminan fidusia, eksekusi.

Krisis ekonomi merupakan kasus yang sangat ditakuti oleh setiap negara di dunia. Hal ini membuat setiap negara berusaha untuk memperkuat ketahanan ekonomi. Oleh karena itu, Indonesia sebagai negara yang sedang berkembang berupaya untuk menjaga stabilitas ekonominya demi kesejahteraan rakyatnya. Rakyat merupakan prioritas utama dalam setiap negara, khususnya republik ini yang menganut asas demokrasi. Oleh karenanya, rakyat memegang peran penting dalam perkembangan negara.

Ekonomi kerakyatan merupakan sistem ekonomi yang berbasis pada kekuatan ekonomi rakyat. Ekonomi ini sebagai kegiatan ekonomi atau usaha ditentukan oleh rakyat kebanyakan (popular) secara swadaya dengan mengelola sumberdaya ekonomi apa saja yang dapat diusahakan dan dikuasainya. Hal ini selanjutnya disebut Usaha Kecil Menengah 
(UKM), terutama meliputi sektor pertanian, peternakan kerajinan, makanan, dan sebagainya. Usaha ini ditujukan untuk memenuhi kebutuhan dasarnya dan keluarganya tanpa harus mengorbankan kepentingan masyarakat lainnya. Setiap bank di Indonesia berupaya untuk membantu setiap masalah masyarakat dengan tujuan untuk mengembangkan usaha-usaha yang telah dijalankan oleh masyarakat. Setiap usaha yang dirintis oleh masyarakat tersebut memberikan kontribusi besar terhadap perekonomian bangsa.

Bank islam didasarkan pada prinsip

hukum islam. Sistem bank islam menawarkan fungsi dan jasa yang sama dengan sistem bank konvensional meskipun diikat oleh prinsip-prinsip islam. Sistem operasi dari bank islam berdasarkan prinsip pembagian keuntungan dan kerugian. Bank islam tidak mengenakan bunga untuk dana yang ditawarkan ke konsumen, tetapi memperkirakan pertambahan dana yang akan datang, yang merupakan hasil dari penggunaan dana tersebut. $\mathrm{Di}$ sisi lain, nasabah mendapatkan bagiannya dari keuntungan bank yang berdasarkan rasio yang ditetapkan sebelumnya. Terlebih juga bank syariah diawasi oleh Dewan Syariah Nasional - Majelis Ulama Indonesia yang selanjutnya akan disebut dengan DSN MUI lebih menjaga transaksi yang dilakukan di bank syariah. Sehingga, masyarakat tidak perlu khawatir lagi dalam masalah kehalalan setiap transaksi yang dilakukan.

Pokok di dalam eksekusi jaminan fidusia yaitu barang jaminan yang diikat dengan jaminan fidusia agar memiliki kekuatan hukum ketika terjadi wanprestasi dari kedua belah pihak. Bila melihat praktik di Bank Syariah Mandiri kota Malang, hanya terdapat jaminan yang berupa barang bergerak saja seperti mobil dan motor yang di terima untuk diikat dalam akta jaminan fidusia. Eksekusi merupakan jalan terakhir yang diambil oleh BSM karena debitur sudah wansprestasi atau tidak mengembalikan pinjaman dengan tepat waktu. Dari peraturan yang telah berlaku baik berupa Undang-undang Nomor 42 Tahun 1999 Tentang jaminan fidusia dan DSN MUI nomor 68 tahun 2008. Peraturan tersebut sangat berbeba di dalam praktek yang terjadi di lapangan khususnya di Bank syariah mandiri kota malang, inilah mengapa penelitian ini terfokus dalam di BSM tersebut, karena terdapat kesenjangan antara peraturan dan praktek yang telah terjadi. Sehingga perlu adanya penelitian untuk meluruskan praktek yang telah terjadi selama ini di bank syariah mandiri kota malang.

Dari latar belakang inilah, maka peneliti ingin memecahkan berbagai masalah berikut. Pertama, bagaimanakah pelaksanaan pemberian jaminan fidusia di Bank Syariah Mandiri kota Malang. Kedua, bagaimana pelaksanaan eksekusi terhadap jaminan fidusia apabila debitur wanprestasi di Bank Syariah Mandiri kota Malang. Ketiga, bagaimana Tinjauan DSN MUI terhadap eksekusi jaminan fidusia di Bank Syariah Mandiri kota Malang?

\section{Metodologi Penelitian}

Jenis penelitian ini merupakan penelitian hukum sosiologis atau empiris, yang mencakup, penelitian terhadap identifikasi hukum (tidak tertulis) dan penelitian terhadap efektivitas hukum. ${ }^{1}$ Dapat disebut pula dengan penelitian lapangan. Penelitian ini berbasis pada ilmu hukum normatif (peraturan perundangan), tetapi bukan mengkaji mengenai sistem norma dalam aturan perundangan, namun mengamati bagaimana reaksi dan interaksi yang terjadi ketika sistem norma itu bekerja di dalam masyarakat. ${ }^{2}$ Penelitian ini mengkaji tentang praktik eksekusi Jaminan Fidusia di BSM kota Malang di tinjau dari DSN MUI Nomor 68 Tahun 2008.

Penelitian ini dilakukan di kantor Bank Syariah Mandiri kota Malang Jawa Timur. BSM kota Malang dipilih sebagai lokasi penelitian karena merupakan kantor cabang yang membawahi beberapa kantor BSM lainnya yang berada dekat dari Malang sehingga sangat memungkinkan bagi

\footnotetext{
${ }^{1}$ Soerjono Soekanto, Pengantar Penelitian Hukum, (Jakarta: UI Press, 1983), h. 51.

${ }^{2}$ Mukti Fajar dan Yulianto Achmad, Dualisme Penelitian Hukum Normatif dan Empiris, (Yogyakarta: Pustaka Pelajar, 2010), h. 47.
} 
peneliti untuk mendapatkan informasi mengenai judul yang penulis ajukan. Lokasi dari kantor tersebut sangat strategis karena berada di perkotaan dan jalan utama menuju arjosari maupun alun-alun Malang serta berada di bebarapa kecamatan daerah tersebut. Memudahkan bagi nasabah dalam melakukan transaksi baik dari menabung maupun melakukan pinjaman-meminjam seperti apa yang sedang diteliti oleh penulis.

Pendekatan yang di gunakan dalam penelitian skripsi ini adalah metode pendekatan kualitatif. Pendekatan kualitatif adalah suatu cara analisis hasil penelitian yang menghasilkan data deskriptif analitis, yaitu data yang ditanyakan oleh responden secara tertulis atau lisan serta juga tingkah laku yang nyata, yang diteliti dan dipelajari sebagai suatu yang utuh. Oleh karena itu, peneliti harus dapat menentukan data mana atau bahan hukum mana yang memiliki kualitas sebagai data atau bahan hukum yang diharapkan atau diperlukan dan data atau bahan hukum mana yang tidak relevan dan tidak ada hubungannya dengan materi penelitian. ${ }^{3}$ Pendekatan ini mengkaji tentang tata cara dalam eksekusi jaminan fidusia yang terjadi di BSM kota Malang.

Data primer dalam penelitian hukum adalah data yang diperoleh terutama dari hasil penelitian empiris, yaitu penelitian yang dilakukan langsung di dalam masyarakat, sedangkan data hukum sekunder dalam penelitian hukum adalah data yang diperoleh dari hasil kepustakaan atau penelaahan terhadap berbagai literatur atau bahan pustaka yang berkaitan dengan masalah atau materi penelitian yang sering disebut sebagai bahan hukum. ${ }^{4}$

Data primer dalam penelitian hukum dapat dilihat sebagai data yang merupakan perilaku hukum dari warga masyarakat. Soerjono Soekanto ${ }^{5}$ mengatakan bahwa:

\footnotetext{
${ }^{3}$ Mukti Fajar dan Yulianto Achmad, Dualisme Penelitian Hukum Normatif dan Empiris, h. 192.

4 Mukti Fajar dan Yulianto Achmad, Dualisme

Penelitian Hukum Normatif dan Empiris, h. 156.

5 Soerjono Soekanto, Pengantar Penelitian Hukum, h. 156.
}

Hukum merupakan bagian dari pergaulan hidup manusia, yang terwujud dalam perilaku manusia maupun di dalam perangkat kaidah-kaidah yang sebenarnya juga merupakan abstraksi dari perilaku manusia. Dengan demikian, maka perilaku manusia dan ciri-cirinya yang mencakup perilaku verbal dan perilaku nyata (termasuk hasil dari perilaku manusia dan ciri-cirinya tersebut), seperti peninggalan fisik, bahanbahan tertulis dan data hasil simulasi merupakan data yang penting dalam penelitian hukum.

Data sekunder atau data kepustakaan atau dikenal dengan bahan hukum dalam penelitian hukum seperti ada kesepakatan yang tidak tertulis dari para ahli peneliti hukum, bahwa bahan hukum itu berupa literatur. $^{6}$

Adapun jenis data dalam penelitian ini ada dua. Pertama Sumber Data Primer, yaitu data yang diperoleh secara langsung dari sumber utama yakni para pihak yang menjadi obyek dari penelitian ini. Data primer dalam penelitian ini adalah data yang dihasilkan melalui wawancara secara langsung dengan informan dengan 2 orang saja, ${ }^{7}$ data primer yang di dapatkan dalam penelitian ini melalui hasil wawancara dengan beberapa pegawai BSM kota Malang yang kompeten di bidang eksekusi jaminan fidusia. Adapun informan dalam penelitian ini adalah Bapak Didit Ferdyanto Bagian Marketing AO (Account Officer) dan Bapak Kholis Khoironi Bagian Marketing (Account Maintanance).

Kedua Data sekunder, yaitu data penunjang data primer yang berasal dari buku atau literatur yang berkaitan dengan objek penelitian khususnya buku yang berkaitan dengan hukum jaminan fidusia, Fatwa DSN MUI, UUJF, Perbankan Syariah.

Teknik pengumpulan data primer ini ditelusuri dan diperoleh melalui dua cara. Pertama, wawancara langsung dengan para karyawan BSM kota Malang yang menangani

\footnotetext{
${ }^{6}$ Mukti Fajar dan Yulianto Achmad, Dualisme Penelitian Hukum Normatif dan Empiris, h. 157.

${ }^{7}$ Burhan Bungin, Metodologi Penelitian Sosial; FormatFormat Kuantitatif dan Kualitatif, (Surabaya: Airlangga Press, 2001), 129.
} 
kasus tersebut. Kedua, dokumentasi pengumpulan data dengan cara mengambil data dari dokumen yang merupakan suatu pencatatan formal dengan bukti otentik. Pengumpulan data ini diperoleh dari penelusuran kepustakaan, penelusuran informasi, dan mempelajari buku-buku atau literaturliteratur yang berkaitan dengan masalah eksekusi jaminan fidusia.

Setelah semua data yang digunakan dalam penyusunan penelitian ini terkumpul (data lapangan maupun data kepustakaan), maka dilakukan analisis data. Analisis data yang diperoleh baik melalui wawancara dan data dari studi kepustakaan akan diuraikan dan dijelaskan mengenai keadaan yang sebenarnya dan apa yang terjadi didalamnya.

Adapun analisis data yang digunakan oleh penulis adalah metode yang bersifat deskriptif analitik. Penelitian deskriptif adalah penelitian yang bertujuan untuk menyusun gambaran atau potret suatu permasalahan tentang pola dan problematika. ${ }^{8}$ Penulis memaparkan data yang telah diperoleh dari hasil penelitian di lapangan melalui wawancara dan studi kepustakaan, peneliti melakukan wawancara dengan 2 orang pegawai bank syariah mandiri yang menangani kasus sengketa eksekusi jaminan fidusia. Wawancara dilakukan selama 2 hari walaupun hanya 2 hari penelitian yang di lakukan di bank tersebut. Akan tetapi data yang diperoleh sudahlah sangat maksimal karena kedua pegawai tersebut sudah kompeten dibidang yang akan diteliti oleh peneliti. Tidak hanya wawancara saja, akan tetapi hasil dari wawancara (praktek dilapangan) penulis benturkan dengan referensi-refernsi baik dari buku-buku maupun undang-undang serta fatwa dewan syariah nasional yang telah peneliti kumpulkan untuk di jadikan bahan dalam hasil penelitian. Sehingga hasil dapat dijadikan pedoman dalam pemecahan permasalahan mengenai eksekusi jaminan fidusia di BSM kota Malang khususnya di Bank Syariah khususnya bagi mahasiswa syariah jurusan hukum bisnis syariah.

\section{Hasil Penelitian}

\footnotetext{
8 Endang Poerwanti, Dimensi-Dimensi Riset Ilmiah, (Malang: UMM Pers, 1998), hlm. 26.
}

Pembiayaan adalah penyediaan dana dan pemberian fasilitas untuk mendukung investasi atau usaha baik dari mikro maupun makro yang telah direncanakan berdasarkan kesepakatan antara bank dengan nasabah ataupun pihak lain yang mewajibkan pihak yang dibiayai untuk mengembalikan uang atau tagihan tersebut setelah jangka waktu tertentu dengan imbalan atau bagi hasil.

Terdapat pengertian yang dimuat dalam undang-undang nomor 10 tahun 1998 tentang Perbankan yaitu:

"Pembiayaan berdasarkan Prinsip

Syariah adalah penyediaan uang atau tagihan yang dipersamakan dengan itu berdasarkan persetujuan atau kesepakatan antara pihak bank dan pihak lain yang mewajibkan pihak dibiayai untuk mengembalikan uang atau tagihan tersebut setelah jangka waktu tertentu dengan imbalan atau bagi hasil"

Pengertian perbankan syariah dimuat dalam Pasal 25 Undang-undang nomor 21 tahun 2008 tentang perbankan syariah. Didit Ferdyanto $^{9}$ Mengatakan bahwa BSM memiliki prinsip dasar sebelum menjalankan suatu pembiayaan, agar tidak merugikan salah satu pihak, yaitu prinsip keadilan, prinsip kemitraan, prinsip keterbukaan, dan prinsip universalitas.

berpedoman pada UUJF pasal 6 sebagai landasan utama untuk melakukan sebuah transaksi yang dibebankan melalui akta pembebanan jaminan fidusia yaitu: Identitas pihak pemberi dan penerima fidusia, Data perjanjian pokok yang dijamin fidusia, Uraian mengenai benda yang menjadi objek jaminan fidusia, Nilai penjaminan, dan Nilai benda yang menjadi objek jaminan fidusia.

Obyek Jaminan fidusia adalah segala sesuatu yang dapat dimiliki dan dialihkan baik yang berwujud, yang terdaftar maupun yang tidak terdaftar, yang bergerak maupun yang tidak bergerak yang tidak dapat dibebani dengan Hak Tanggungan atau Hipotek (Pasal 1 ayat 4 UUJF). ${ }^{10}$

Praktik yang terjadi di BSM kota Malang terkait objek jaminan fidusiatidak

\footnotetext{
${ }^{9}$ Didit Ferdyanto, wawancara, (Malang, 13 Mei 2014).

${ }^{10}$ Lembaran Negara Republik Indonesia Tahun 1999 Nomor 168.
} 
sama halnya dengan aturan yang berlaku. Hasil wawancara dari salah satu pegawai BSM kota Malang. ${ }^{11}$ Bahwasannya praktik di BSM tersebut hanya menerima objek jaminan fidusia berupa barang bergerak saja yaitu mobil dan motor. Dalam pelaksanaannya benda jaminan memiliki nominal dalam membiayai benda tersebut. Biaya tersebut terbagi kedalam 2 (dua) golongan. Pertama adalah Pembiayaan di Atas Seratus Juta. Pembiayaan yang masuk minimal seratus juta (100.000.000) yaitu kendaran bergerak berupa mobil. Semua pembiayaan minimal seratus juta dan dibebani oleh akta pembebanan jaminan fidusia. Bahwa benda tersebut akan segera di daftarkan di kantor pendaftaran jaminan fidusia di daerah tersebut. Dikarenakan untuk melindungi benda apabila sewaktu-waktu terjadi wanprestasi dari debitur. Karena sudah tidak mampu lagi memenuhi kewajiban dalam membayar hutang kepada BSM. Ini sesuai dengan UUJF pasal 11 ayat 1 yaitu "Benda yang dibebani dengan jaminan fidusia wajib didaftarkan"

Kedua adalah pembiayaan di Bawah Seratus Juta. Pembiayaan yang masuk minimal lima puluh juta (50.000.000) yaitu kendaraan bergerak berupa motor. Pihak BSM akan menerima pembiayaan benda bergerak barupa motor. Dengan syarat motor tersebut memenuhi atau masuk minimal yang di syaratkan dari pihak bank. Contohnya: ketika terjadi pembiayaan motor, dan yang dibiayai adalah motor yang berharga sepuluh juta (10.000.000) maka harus ada lima (5) motor untuk memenuhi persyaratan tersebut. Dan ketika sudah terjadi pembiayaan dengan menggunakan Akta Pembebanan Jaminan fidusia. Akan tetapi dalam kasus ini tidak sama halnya dengan pembiayaan mobil, ketika terjadi pembiayaan mobil maka pada saat itu juga akan segera di daftarkan benda tersebut kepada kantor pendaftaran Jaminan fidusia, tetapi tidak sama halnya dengan motor. Ketika terjadi pembiayaan maka tidak didaftarkan secara langsung ke kantor pendaftaran jaminan fidusia, tetapi pen-

\footnotetext{
${ }^{11}$ Didit Ferdyanto, Wawancara, (Malang, 13 Mei 2014).
}

daftarannya akan ditunda sampai ketika debitur terjadi wanprestasi, maka pada saat itu juga akan segera di daftarkan oleh pihak kreditur atau pihak BSM untuk mengamankan apabila terjadi eksekusi. Apabila benda jaminan fidusia didaftarkan maka akan mempermudah kreditur dalam melakukan eksekusi benda atau objek jaminan fidusia tersebut.

UUJF memberikan penjelasan dalam pasal 1 ayat 4 yaitu: "benda adalah segala sesuatu yang dapat dimiliki dan dialihkan, baik yang berwujud maupun yang tidak berwujud, yang terdaftar maupun yang tidak terdaftar, yang bergerak maupun yang tidak bergerak yang tidak dapat dibebani hak tanggungan atau hipotik".

Dalam praktiknya di BSM kota Malang hanya menerima di bidang barang bergerak saja yang berupa mobil dan motor, serta memiliki nominal paling seidikit dalam pembiayaan yang dilakukan oleh BSM kota Malang, yaitu: Pertama, pembiayaan kendara bermotor, minimal bernilai lima puluh juta rupiah (50.000.000). Contohnya: pembiayaan motor agar dapat dibiayai melalui akta pembebanan jaminan fidusia, motor tersebut harus bernilai lima puluh juta rupiah. Jika motor tersebut hanya bernilai sepuluh juta rupiah maka harus ada lima motor agar senilai yang menjadi ketentuan oleh pihak BSM kota Malang.

Kedua, pembiayaan kendaraan mobil, yang minimal bernilai seratus juta rupiah (100.000.000). Apapun merek dan tahun berapa produksi mobil tersebut asalkan bernialai seratus juta rupiah maka dari pihak BSM akan memberikan pinjaman yang diikat dengan jaminan fidusia. Akad yang digunakan dalam pembiayaan jaminan fidusia ini dibebankan melalui akta pembebanan jaminan fidusia atau menggu-nakan akad murabahah atau ijarah muntahiya bittamlik. $^{12}$

Adapun Eksekusi jaminan fidusia adalah penarikan dan penjualan benda yang menjadi objek jaminan fidusia. Pelaksanaan eksekusi jaminan fidusia dilakukan oleh pihak kreditur dalam hal debitur cidera janji

\footnotetext{
${ }^{12}$ Didit Ferdyanto, wawancara, (Malang, 13 Mei 2014).
} 
atau wanprestasi sebagaimana aturan pasal 29 UUJF. ${ }^{13}$ Terdapat tiga cara dalam hal eksekusi jaminan fidusia.

Pertama, apabila debitur atau pemberi fidusia cidera janji, eksekusi terhadap benda yang menjadi obyek jaminan fidusia dapat dilakukan dengan cara: ${ }^{14}$ pelaksanaan titel eksekutorial sebagaimana dimaksud dalam pasal 15 ayat (2) oleh penerima fidusia; penjualan benda yang menjadi obyek jaminan fidusia atas kekuasaan penerima fidusia sendiri melalui pelelangan umum dan mengambil pelunasan piutangnya dari hasil penjualan; penjualan di bawah tangan yang dilakukan berdasarkan kesepakatan pemberi dan penerima fidusia jika dengan cara demikian dapat diperoleh harga tertinggi yang menguntungkan para pihak.

Kedua, pelaksanaan penjualan sebagaimana dimaksud dalam ayat (1) huruf $\mathrm{c}$ dilakukan setelah lewat waktu 1 (satu) bulan sejak diberitahukan secara tertulis oleh pemberi dan/atau penerima fidusia kepada pihak-pihak yang berkepentingan dan diumumkan sedikitnya dalam 2 (dua) surat kabar yang beredar di daerah yang bersangkutan.

Pasal 15 ayat 2 tersebut adalah sertifikat jaminan fidusia sebagaimana dimaksud dalam ayat 1 mempunyai kekuatan hukum yang eksekutorial yang sama dengan putusan pengadilan yang telah memperoleh kekuatan hukum tetap. Mempunyai hukum yang tetap disebabkan karena dalam sertifikat ja-minan fidusia dicantumkan kata-kata "Demi Keadilan Berdasarkan Ketuhanan Yang Maha Esa". Apabila debitur wanprestasi atau tidak mengembalikan hutang pada waktunya, maka kreditur bisa melakukan eksekusi benda jaminan fidusia tersebut. Akan tetapi, pihak BSM tidak menggunakan istilah ini. Karena akan menimbulkan dampak negatif, pihak BSM

\footnotetext{
${ }^{13}$ Retnowulan Sutantio, Penelitian Tentang Pelindungan Hukum Eksekusi Jaminan Kredit, (Jakarta: Bina Cipta, 1997), h. 2

${ }^{14}$ Lembaran Negara Republik Indonesia Tahun 1999 Nomor 168.
}

selalu menggunakan prinsip kekeluargaan dalam menyelesaikan dalam hal eksekusi jaminan fidusia yang terjadi.

Ada beberapa tahapan dalam melakukan eksekusi di BSM ketika debitur sudah terlambat membayar. Pertama, ketika debitur terlambat membayar satu sampai lima hari, pihak BSM akan melakukan pengecekan via telepon. Kedua, ketika debitur terlambat membayar lima sampai sepuluh hari, maka dari pihak BSM akan mendatangi rumah debitur untuk membicarakan secara baik atau menanyakan masalah apa yang dihadapi oleh debitur sehingga tidak membayar tepat waktu. Ketiga, apabila debitur tetap tidak membayar sepuluh hari sampai satu bulan maka pihak bank akan menyita barang jaminan untuk dilakukan pelelangan sesuai aturan yang berlaku. Akan tetapi, BSM memiliki kebijakan sendiri dalam penanganan debitur, ketika akan melakukan eksekusi barang jaminan tersebut. Kebijakan tesebut yaitu BSM memberikan kebebasan kepada debitur untuk menjual secara pribadi barang eksekusi tersebut sehingga debitur akan mendapatkan harga yang lebih sesuai dan pantas untuk barang tersebut, serta di dalam penjualan tersebut akan diawasi oleh pihak BSM. Akan tetapi, ketika debitur tidak dapat menjual atau kesusahan dalam menjual barang jaminan tersebut maka pihak BSM akan melakukan penjualan itu sendiri dengan cara lelang. Dalam konteks ini, pihak yang berwenang atau menangani kasus eksekusi jaminan fidusia yaitu Didit Ferdyanto. $^{15}$

Tidak hanya dengan aturan yang telah ada, BSM memiliki tabungan yang berupa LASNA BSM (Lembaga Amil Zakat Nasional), dana yang diperoleh dari nasabah yang masih dapat dibantu, debitur dikenakan denda atau di dalam hukum islam yang dijalankan oleh pihak BSM adalah biaya takwit. Biaya ini bukan masuk kedalam kas BSM untuk sebagai biaya operasional melainkan masuk kedalam kas LASNA BSM (Lembaga Amil Zakat Nasional), dana-dana

\footnotetext{
${ }^{15}$ Bapak Didit Ferdyanto, wawancara, (Malang, 13 Mei 2014).
} 
tersebut yang selalu disumbangkan bagi rakyat-rakyat yang membutuhkan. ${ }^{16}$

Macet 1-5 hari BSM melakukan

pengecekan via telepon.

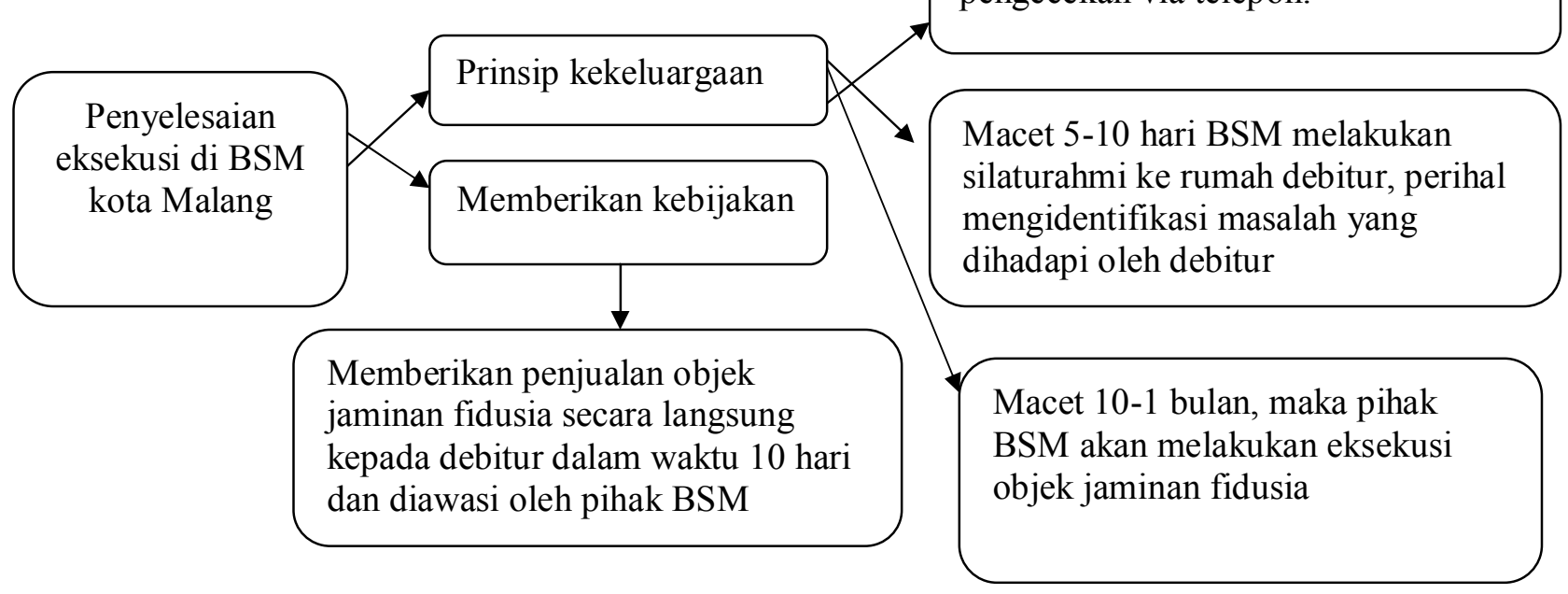

\section{Tinjauan DSN MUI terhadap Eksekusi Jaminan Fidusia di Bank Syariah Mandiri Kota Malang}

Dari fatwa DSN MUI bahwa aturan dalam melakukan transaksi yang dilakukan di dunia perbankan syariah, semua telah ada aturan maupun fatwa yang telah mengatur hal tersebut. Salah satunya fatwa DSN MUI No. 68 tahun 2008 yaitu menimbang:

Bahwa salah satu bentuk jasa pelayanan Lembaga Keuangan Syariah (LKS) yang menjadi kebutuhan masyarakat adalah pinjaman atau transaksi lain uang menimbulkan utang-piutang dengan memberikan jaminan barang dengan ketentuan barang tersebut masih dikuasai dan digunakan oleh pihak berutang.

Bahwa pihak berpiutang berhak dengan mudah untuk melakukan eksekusi atas barang agunan yang masih dikuasai oleh peminjam jika terjadi wanprestasi.

Berikut alur penyelesaian eksekusi dari hasil wawancara ${ }^{17}$ di BSM kota Malang, yaitu:

\footnotetext{
${ }^{16}$ Bapak Kholis Khoironi, Wawancara, (Malang, 14 Mei 2014).

${ }^{17}$ Bapak Didit Ferdyanto, Wawancara, (Malang, 13 Mei 2014).
}

Bahwa agar cara tersebut dilakukan sesuai dengan prinsip-prinsip syariah, Dewan Syariah Nasional MUI memandang perlu menetapkan fatwa tentang Rahn Tasjily untuk dijadikan pedoman.

Dapat ditarik kesimpulan bahwa, dengan berpedoman dengan hasil penelitian yang dilakukan oleh penulis di BSM kota Malang, bahwa eksekusi yang dilakukan di BSM sudah sesuai dengan prinsip syariah yaitu memiliki prinsip-prinsip yang tidak keluar dari prinsip syariah (prinsip kekeluargaan, prinsip kehati-hatian, dan lain-lain). Akan tetapi, semestinya aturan yang digunakan dalam hal melakukan perjanjian dan eksekusi menggunakan akad rahn tasjily. Karena, berhubung bank syariah harus tunduk dalam prinsip syariah yang dikeluarkan mui yang sesuai dalam peraturan perbankan syariah pasal 26. Hal ini disebabkan masih terdapat beberapa poin fatwa yang keluarkan DSN MUI sebagai pedoman perbankan syariah yang berada di Indonesia yang dilewatkan atau tidak dijalankan oleh BSM kota Malang. Poinpoin tersebut adalah: Pertama, dalam penyelesaian sengketa semestinya menyelesaikan melalui Badan Arbritase Syariah Nasional atau melalui Pengadilan Agama sesuai fatwa DSN MUI dalam ketentuan penutup nomor satu. Kedua, Dalam akad yang digunakan dalam melakukan perjanjian dengan nasabah, tidak meng- 
gunakan akad yang telah ditetapkan oleh DSN MUI yaitu Rahn Tasjily.

Jika mengacu dari kedua alasan tersebut, dapat difahami bahwa BSM kota Malang masih belum tepat dalam mengacu kepada aturan yang berlaku. Kinerja atau transaksi yang dilakukan oleh perbankan syariah seluruh Indonesia, khususnya BSM kota Malang, selalu menggunakan akadakad yang dikeluarkan oleh DSN MUI sebagai lembaga yang berwenang.

\section{Kesimpulan}

Dari pembahasan dan anlisis diatas, maka dapat disimpulkan beberapa hal. Pertama, berkaitan dengan praktik pembiayaan yang dilakukan oleh BSM kota Malang, setelah dilakukan wawancara dengan account officer yaitu Bapak Didit Ferdyanto. Pembiayaan yang dilakukan BSM kota Malang dapat dilihat dari dua kacamata aturan yaitu: pertama, dalam aturan UUJF BSM sudah melakukan praktik pembiayaan jaminan fidusia dengan baik dan benar. Sedangkan dari kacamata DSN MUI. BSM sudah melakukan transaksi sesuai dengan prinsip syariah, karena tidak terjadi kesalahankesalahan yang tidak sesuai prinsip syariah. Hanya saja, tidak menggunakan akad yang tepat yang telah dikeluarkan oleh DSN MUI sebagaimana mestinya. Pembiayaan yang diterima oleh BSM yaitu barang bergerak berupa mobil dan motor yang masih belum sesuai dengan aturan UUJF yang telah berlaku. Serta memiliki nominal yang telah ditetapkan oleh pihak BSM yaitu pertama, pembiayaan minimal lima puluh juta. Kedua, pembiayaan diatas seratus juta.

Kedua, terkait penyelesaian eksekusi yang dilakukan oleh pihak BSM kota Malang sudah sesuai dengan prinsip syariah, dari hasil wawancara dari salah satu pegawai BSM di bidang marketing. Bahwa tidak selamanya aturan akan selalu diutamakan karena masih terdapat caracara yang lebih baik dalam hal melakukan eksekusi sehingga tidak merugikan salah satu pihak. Perturan akan dilaksanakan ketika debitur sudah tidak dapat diajak negosiasi lagi, maka hukumlah yang akan dilaksanakan demi mendapatkan keadilan serta menyelamatkan dari kerugian yang melebih. Kebijakan merupakan jalan yang pertamakali yang dilaksanakan oleh BSM karena dari kebijakan tersebut merupakan salah satu jalan yang sesuai dengan prinsip syariah.

Ketiga, tinjauan hukum islam terhadap eksekusi yang dilakukan oleh BSM kota Malang, sebagai lembaga yang berwenang dalam memberikan masukan serta mengeluarkan fatwa tentang transaksi yang dilakukan oleh perbankan syariah khususnya BSM kota Malang. Bahwa dalam transaksi yang dilakukan menurut DSN MUI sudah sesuai dengan prinsip syariah meskipun tidak semua aturan yang telah diberlakukan yang digunakan oleh BSM. Aturan yang pertama, dalam aturan UUJF dalam pasal 29 yang memuat tatacara dalam hal eksekusi, intinya sebelum melakukan eksekusi setelah adanya surat peringatan maka harus adanya pemberitaan melalui surat kabar yang beredar di kota tersebut. Akad yang digunakan belum sesuai yang mana mestinya, yaitu menggunakan akad Rahn tasjily yang dikeluarkan oleh DSN MUI. kedua, penyelesaian eksekusi belum menggunakan peradilan agama dan arbritase nasional.

\section{DAFTAR RUJUKAN}

Achmad ,Mukti Fajar dan Yulianto. Dualisme Penelitian Hukum Normatif dan Empiris. Yogyakarta: Pustaka Pelajar, 2010.

Bungin,Burhan. Metodologi Penelitian Sosial; Format-Format Kuantitatif dan Kualitatif. Surabaya: Airlangga Press, 2001.

Ferdyanto, Didit. Wawancara, Account officer marketing. Malang: 13 April 2014.

Khoironi, Kholis. Wawancara. Malang: 14 Mei 2014

Lembaran Negara Republik Indonesia Tahun 1999 Nomor 168.

Poerwanti, Endang. Dimensi-Dimensi Riset Ilmiah. Malang: UMM Pers, 1998. 
Soekanto, Soerjono. Pengantar Penelitian Hukum. Jakartan: Penerbit Universitas Indonesia Press, 1986.

Sutantio, Retnowulan. Penelitian Tentang Pelindungan Hukum Eksekusi Jaminan Kredit. Jakarta: Bina Cipta, 1997. 